\title{
PRZEWODNICTWO W SAKRALNYCH OBIEKTACH
}

\section{Wstęp}

Duża część miejsc odwiedzanych przez turystów, nierzadko pod okiem przewodników, to obiekty sakralne: kościoły, kaplice, klasztory, cmentarze, ośrodki pielgrzymkowe, wraz z ich otoczeniem. Można do tej grupy zaliczyć, z pewnymi zastrzeżeniami, muzea utworzone przez instytucje kościelne, o ile są w nich eksponowane obiekty kultu, które dziś znajdują się już poza świątyniami, jednakże powstały w celach religijnych (obrazy, rzeźby, sprzęty liturgiczne itp.). Autor artykułu zamierza podzielić się refleksją na temat roli osób będących przewodnikami prezentującymi turystom święte miejsca, a w szczególności wykazać, że wejście w ich obszar wymaga innego przygotowania (po części zupełnie odmiennego) niż w przypadku obiektów świeckich. Autor, jako teolog, opiera swe analizy na teologicznych przesłankach, jednakże odnosi się także do zasad - jak się wydaje - ogólnie akceptowanych w turystycznych środowiskach. Nie pozostaje w kręgu teologicznych analiz teoretycznych, a stara się wskazać wnioski praktyczne, dotyczące osób odwiedzających sakralne obiekty. Równocześnie uważa, że bez względu na światopogląd przewodników i turystów pewna doza teologicznej wiedzy jest konieczna, aby właściwie zrozumieć to, co prezentują bądź podziwiają. Nie sposób bowiem poznać całej prawdy o odwiedzanym obiekcie sakralnym bez sięgnięcia do motywów jego powstania i funkcjonowania. To, co nazywamy obiektami sakralnymi, zostało stworzone w celach religijnych, by ułatwić osobom wierzącym kontakt ze sferą pozaziemska, z Bogiem, czy też - jeśli mówimy o religiach spoza kręgu chrześcijaństwa $-z$ bóstwami judaizmu bądź islamu. Dla osób wierzących wiedza ta stanie się pomocą w pogłębianiu ich wiary. Innym posłuży do zachowania właściwego szacunku wobec tego, co podziwiają. 


\section{Sacrum i profanum}

W celu rozwiązania przedstawionej kwestii należy przede wszystkim w syntetyczny sposób przypomnieć, co rozumiemy pod pojęciem sacrum, stojącym w opozycji do profanum. Jest ono używane w religioznawstwie nie tylko przez chrześcijańskich myślicieli i dotyczy wszystkiego, co związane z przejawami transcendentnych, czyli pozaziemskich, mocy. W związku z tym wydziela się je ze sfery powszedniości, ziemskości, określanej pojęciem profanum. Sacrum zawiera zatem odmienność od tego, co ziemskie. Wywołuje ono w człowieku świadomość obecności tajemnicy (misterium) i budzi zdziwienie, a nawet napawa grozą (mysterium tremendum). Co ciekawe, równocześnie przyciąga go i fascynuje (mysterium fascinosum) (Grodź, 2002). Z praktycznego punktu widzenia - a dotyczy to przede wszystkim obiektów sakralnych - sacrum rozumie się jako wyłączenie ze sfery profanum. Jest to wydzielenie jakiegoś obiektu bądź przedmiotu z użytku świeckiego i przeznaczenie go do wykorzystania w celach religijnych. Tak się dzieje, gdy uroczystym aktem zostaje poświęcony budynek nowego kościoła bądź w mniejszej skali - przedmiot służący kultowi (np. naczynie mszalne, krzyż, obraz, różaniec) (Konieczny, 2012; Żądło, 2012). Przez ów akt widzialny zostaje określona granica pomiędzy tym, co święte, a tym, co świeckie. W kościelnej terminologii używa się do tego rodzaju aktów także określeń „konsekracja” bądź „dedykacja” (Nadolski, 2006). Nie wchodząc w teologiczne i historyczne niuanse przytoczonych terminów, warto dodać, że wspomniane akty oznaczają nie tylko wyłączenie rzeczonych obiektów bądź przedmiotów ze świata profanum, ale uczynienie ich narzędziami uświęcania człowieka, który z nich będzie korzystał (Paszkowska, 2002). Trzeba podkreślić również, że sacrum nie jest oddzielone od świata. W ten sposób powstałby rodzaj getta, obszaru wyizolowanego i zamkniętego, niesłużącego człowiekowi. Przeciwnie, sacrum chce rozlewać się na świat (profanum) i czynić go świętszym, lepszym. Można w tym miejscu nawiązać do Ewangelii. Chrystus jako Bóg przyszedł na świat, by to, co Boże, wszczepić w świat, by go uświęcać i prowadzić do udoskonalenia (Katechizm Kościoła katolickiego, 1994). Jego ostatni nakaz brzmiał: „Idźcie i głoście ewangelię wszelkiemu stworzeniu” (Mk 16,15). Zatem Chrystus pragnął, by jego ewangelia była głoszona we wszystkich zakątkach świata, a jej świętość i dobroć rozchodziły się na całą ziemię, uzdrawiając wszelkie istniejące w nim niedoskonałości. 


\section{Cel powstania sakralnych budowli}

Analizowaną kwestię sacrum i profanum można odnieść do sakralnych budowli. Z jednej strony wznosi się je po to, aby człowiek mógł oddalić się od codziennych spraw oraz znaleźć w nich oazę ciszy i spokoju, zatem aby mieć zapewnione odpowiednie warunki i atmosferę do snucia pogłębionej refleksji nad swoim życiem, uchwycenia go z pewnego dystansu, a zarazem z perspektywy tego, co ostateczne i wieczne, a równocześnie odnalezienia sprzyjających okoliczności pozwalających na skierowanie się ku Bogu w akcie modlitwy. Jest to zatem budowanie swoistego mostu pomiędzy Bogiem a człowiekiem. Świątynie kreują widzialną przestrzeń, w której tworzą się fizyczne warunki do religijnego skupienia, a zarazem jest to strefa niematerialna, w której rozwija się życie duchowe wierzącego. Z drugiej strony, odnośnie do tego, co zostało napisane wcześniej, obiekty sakralne istnieją w tym celu, by to, co święte i nadprzyrodzone, mogło rozlewać się na świat, zmieniać go i udoskonalać. Znajdują się one pośród świata profanum, by wnosić weń impuls dobra.

Omawiane zagadnienie może być dobrze zilustrowane przez przytoczony w dalszej partii tekstu przykład. Mury okalające miejsca święte mają bogatą symbolikę. Niekiedy możemy przy nich spotkać figury aniołów z mieczami w rękach. Mury symbolizują oddzielenie miejsca świętego od świata profanum. Niejako zabezpieczają by to, co świeckie, nie wdarło się do wewnątrz i nie zburzyło porządku oraz panującej tam atmosfery. Aniołowie strzegą tej granicy, by nie została przekroczona przez niepożądane osoby ${ }^{1}$. Jednocześnie w murze istnieją bramy. Są one po to, by człowiek mógł wejść przez nie do środka, a potem wyjść na zewnątrz (Hani, 1998; Kobielus, 2009). Człowiek nie tylko ma prawo, ale jest wręcz zapraszany do wejścia w krąg sacrum, by spotkać się z Bogiem, zostać przez Niego uświęconym i umocnionym Jego nauką. Ma zarazem, zainspirowany przez sacrum, wyjść (powrócić) do świata i wnosić weń impulsy świętości. Taką symbolikę mają przykładowo drzwi święte rzymskich bazylik, otwierane w trakcie obchodów jubileuszy chrześcijaństwa (ostatni raz w 2000 r.). Podobnie z okazji Roku Miłosierdzia (2015-2016) papież Franciszek zachęcił do wyznaczenia we wszystkich diecezjach na świecie „Bram Miłosierdzia”.

${ }^{1}$ Jest tu nawiązanie do rajskiego ogrodu. Gdy Bóg wygnał z raju prarodziców z powodu ich grzechu „postawił przed ogrodem Eden cherubów i połyskujące ostrze miecza, aby strzec drogi do drzewa życia" (Rdz 3, 24). 
Kontynuując rozważania na ten temat, warto zauważyć, że sakralne obiekty tworzą swoisty przedmiot, stanowiący narzędzie pośrednictwa między człowiekiem a Bogiem. Bóg przynależy do rzeczywistości ponadziemskiej, nieosiaggalnej przez ludzkie zmysły. Konieczne jest zatem utworzenie widzialnych narzędzi, pozwalających na przekroczenie bariery dzielącej mieszkańca Ziemi od nadprzyrodzonej tajemnicy. Takimi narzędziami mogą stać się budowle z ich architektura, symboliką i całym wewnętrznym wyposażeniem.

Człowiek wierzący ma dostęp do Boga poprzez Jego objawienie w dwóch źródłach: Księgach Objawionych (Biblia) i tradycji Kościoła. Niemniej i te źródła nie zawsze i nie do końca są dla niego zrozumiałe. Wymagają one ciągłego objaśniania. Przez całe wieki Kościół wykonywał to zadanie na różne sposoby: przez papieskie nauczanie, pracę teologów, katechezę bądź kaznodziejstwo. Jedną z dróg, i to bardzo skuteczna, okazała się droga obrazu, zwana niekiedy Biblia pauperum („Biblia ubogich")2. Znane jest także podobne pojęcie via pulchritudinis („droga piękna") (Benedykt XVI, 2011). Obrazy o tematyce religijnej wiszące w świątyniach, rzeźby, architektura, a nawet połączenie ich z naturalnym otoczeniem przyrody, stanowią ważne narzędzia pedagogiki religijnej ${ }^{3}$. Wszystkie te przedstawienia przez swoją wymowność pozwalają odkryć wiele prawd dotyczących Boga (np. kim jest, jakie przymioty posiada), zilustrować chrześcijańskie nauczanie, prowadząc do jego lepszego zrozumienia, przybliżyć sceny biblijne, postacie świętych i ich dzieła. Podobną funkcję pełnią symbole zawarte w kościelnej sztuce i architekturze. Wykorzystywany w nich jest język form, kolorów, a nawet dźwięków (muzyka kościelna) i zapachu (woń kwiatów i kadzideł). Zarazem pobudzają człowieka do otwarcia się na rzeczywistość transcendentną.

${ }^{2}$ W pierwotnym znaczeniu określenie Biblia pauperum („Biblia ubogich”) odnosi się do średniowiecznego dzieła, składającego się głównie z obrazków przedstawiających sceny biblijne. Później (od ok. XVIII w.) stosowano je do wydań Biblii w obrazkach, przeznaczonych dla osób uboższych, których nie było stać na zakup pełnego tekstu Pisma Świętego. Dziś ten termin stosuje się niekiedy przenośnie do ikonografii zamieszczanej w kościołach, przedstawiającej sceny biblijne, z życia świętych, historii Kościoła. Ma ona znaczenie pouczające, por. np.: Jan Paweł II (1999), Seibert, J. (2007).

${ }^{3}$ Warto zwrócić uwagę na parki otaczające kościoły (sanktuaria). Wybitnym przykładem jest Kalwaria Zebrzydowska z wielkim zielonym terenem, na którym rozmieszczone są tzw. dróżki kalwaryjskie. Wszystko to jest osadzone w malowniczym krajobrazie, charakterystycznym dla Beskidów. Kompozycja małych sakralnych budowli wraz z ich wewnętrznym wyposażeniem w połączeniu z pięknem otaczającej przyrody tworzy niezwykłą atmosferę, sprzyjającą zadumie i modlitwie, a zarazem utwierdza pielgrzymów w wierze (por. Ostrowski, 2001). 
Kościół od początku uznaje, że piękno świata stworzonego jest jedną $\mathrm{z}$ dróg przekonania się o istnieniu Boga.

Zwykło się uważać, że ludzie niepiśmienni, żyjący w poprzednich epokach, w obrazach upatrywali szansę poznawania prawd o Bogu. Tymczasem wiele wskazuje na to, że również dziś, w dobie Internetu, ludzie nie zawsze są chętni do analizowania tekstów pisanych i wracają do obrazu jako środka przekazu. Powstaje jednak pytanie, czy zawsze ten obraz do końca rozumieja, zwłaszcza gdy zawiera on symboliczne treści, nie jest przedstawieniem realistycznym. Wydaje się, że wielu współczesnych ludzi posiada słabo rozwinięte myślenie abstrakcyjne i symboliczne. Mimo wskazanej wcześniej wymowności obrazów, pozostaje zatem stała konieczność ich objaśniania, a to zadanie dla przewodnika i krajoznawcy. Używając współczesnego języka, można powiedzieć, że artyści, zgodnie z rodzajem uprawianej sztuki, zakodowali w swych dziełach pewne religijne prawdy. Dobry przewodnik rozpoznaje ów kod i dokonuje swoistego rozszy frowania, czyli przełożenia na język zrozumiały dla dzisiejszego odbiorcy (turysty).

Analizując omawiane zagadnienie z psychologicznego punktu widzenia, można zauważyć, że obraz jest środkiem pomagającym człowiekowi w koncentracji uwagi i zmysłów. Budzi także uczucia: zachwytu, wzniesienia umysłu ku temu, co wspaniałe, lub grozy wobec ponadziemskich sił; poczucia majestatu i konieczności pochylenia się przed czymś, co jest wielkie, albo lęku przed karą (wspomniane wcześniej mysterium tremendum i mysterium fascinosum).

Wielka budowla lub mały przedmiot sakralny pozwalają na skupienie uwagi i duchową koncentrację. Między innymi w tym celu nadal powstają religijne obrazy, figury, różańce, świece. Obok wspomnianych wyżej zadań „informacyjnych”, pomagają one osobom wierzącym w ich religijnych praktykach. Kierują myśli ku tajemnicy, wspierają ześrodkowanie uwagi na rozważanej kwestii. Szerzej rzecz ujmując, często istnieje zespół tego rodzaju przedmiotów, np. budynek kościoła (sanktuarium) z jego architekturą i wystrojem, akcją liturgiczną odbywającą się w nim (tony muzyki, dym kadzideł, gesty uczestników, chwile milczenia itp.), jego otoczeniem (np. wspomniane wcześniej parki przykościelne, kalwarie). W owym zespole panuje niepowtarzalna atmosfera, która pomaga w oderwaniu się od tego, co jest na zewnątrz (profanum), by można było lepiej wejść w tajemnicę (sacrum). Służy on duchowemu wyciszeniu, stwarza dogodne warunki do modlitwy i kontemplacji. Tej atmosfery nie można zaburzyć. Przeciwnie, należy pomóc odwiedzającym (turystom) w zrozumieniu tego, gdzie się znaleźli, i pokazać, że sami mogą wejść w tę duchową rzeczywistość. 


\section{Kościół - muzeum czy miejsce „żywej rzeczywistości”?}

Obiekty sakralne są często pełne niezwykle wartościowych zabytków. Turysta, zwłaszcza krajoznawca, chce je obejrzeć. Kościół jako instytucja uznaje owo pragnienie i zaleca, by obiekty te były udostępniane dla wszystkich oraz by odwiedzający byli tam gościnnie przyjmowani. Podkreśla jednak, by podawać im nie tylko informacje z zakresu historii i sztuki, lecz „,na pierwszym miejscu ukazać ich [obiektów - przyp. M.O.] tożsamość i przeznaczenie religijne" (Papieska Rada ds. Migracji i Podróżnych, 2001, nr 14). Świątynie nie są muzeami, zachowującymi bądź tylko przypominającymi historię. Są to przestrzenie, w których tu i teraz rozwija się i pulsuje religijne życie wspólnoty wierzących oraz poszczególnych jej członków. W przekonaniu osób wierzących stanowią miejsca rzeczywistej obecności Boga. Nie są to zatem „martwe budowle”, ale ośrodki żywej wiary, choć zarazem stanowią one świadectwo historii i uczą o niej. W tej przeszłości wierzący odnajdują swe korzenie i tożsamość. W ten sposób historia ciągle kształtuje ich teraźniejszość, czyli trwające nadal życie religijne. Tu trwa modlitwa i udziela się sakramentów świętych formujących chrześcijańską egzystencję. Nawiązując do przeszłości, obiekty sakralne wskazują na kontynuację życia w wieczności. Otwierają zatem człowieka na jego ostateczny cel, jakim jest osiągnięcie wiecznej wspólnoty z Bogiem ${ }^{4}$. Tu można nawiązać do papieskiego przesłania, skierowanego do młodzieży (i nie tylko). Jan Paweł II, mówiąc o dziedzictwie kultury, z którą blisko związana jest wiara, wskazał, że to dziedzictwo należy nie tylko poznać, ale samemu ubogacić i przenieść w przyszłość (Jan Paweł II, 1985). Każde spotkanie z sakralną budowlą powinno doprowadzić do odkrycia nici łączącej teraźniejszość wiary z jej przeszłością i przyszłością, jak też uzmysłowić, że życie każdego z wierzących jest wplecione w tę rzeczywistość.

W związku ze wspomnianą kwestią w dokumentach kościelnych zwraca się uwagę na negatywne zjawisko, ujawniające się w świecie turystyki. Mowa tu o podejściu do religijnych zwyczajów, nie tylko chrześcijańskich, jako do swoistego religijnego teatru. W ten sposób odrywa się je od prawdy religijnego życia, zatracając ich właściwy sens. Rozwijany kult i pobożność osób wierzących zamieniają się w pokaz dla turystów, często żądnych ciekawych przeżyć. Sprawa dotyczy naturalnie również samych wspólnot religijnych, które organizują takie sztuczne przedstawienia dla turystów. Zatem i tu pojawia się konieczność właściwego

${ }^{4}$ Mówił o tym dobitnie Jan Paweł II podczas wizyty w Zakopanem (Jan Paweł II, 1997). 
przygotowania turystów oraz osób tworzących owe obrzędy (por. np. Schlußerklärung..., 1991).

Konkludując, warto zauważyć, że nawet współczesne muzea próbują przekształcać się $\mathrm{w}$ ośrodki, które chca, poprzez stosowanie nowoczesnych technologii prezentacji, przybliżyć życie. Preferuje się w nich przedstawienia multimedialne, żeby nie tylko skuteczniej pobudzić wyobraźnię turystów, ale wręcz pomóc człowiekowi osiągnać rodzaj współuczestnictwa w prezentowanym wydarzeniu ${ }^{5}$.

\section{Zwiedzanie czy nawiedzanie kościoła?}

Jedną z kluczowych kwestii w przypadku analizowanego zagadnienia można zilustrować poprzez rozróżnienie dwóch pojęć -,„zwiedzania” i „nawiedzania”. Turysta zwiedza starówkę miasta, muzeum, park, a także kościół. U podstaw czynności zwiedzania leży pragnienie zaspokojenia ciekawości, chęć poznania jakiegoś obiektu, zaznajomienia się z jego wyglądem, walorami artystycznymi i historią. Turysta mający takie podejście staje się jednak jedynie zewnętrznym obserwatorem. Niekoniecznie dociera do istoty rzeczy. Słowo „nawiedzenie” pojawia się w kontekście Ewangelii, gdy Maryja nawiedza swą krewną Elżbietę w Ein Karim (Łk 1, 39-56). Obie niewiasty wchodzą ze sobą w relacje. Co ważniejsze, owa scena ma charakter religijny. Podczas niej Matka Boża wygłasza hymn Magnificat, który do dziś jest jedną z najznamienitszych modlitw Kościoła. Termin „nawiedzenie” koreluje z określeniem "odwiedziny", z którym kojarzy się coś więcej niż tylko przyjście do kogoś bądź obejrzenie miejsca. Także i tu pojawia się element wejścia $\mathrm{w}$ relacje $\mathrm{z}$ drugim człowiekiem (z rodzina, przyjaciółmi, znajomymi) (por. Odwiedziny, 2018).

Określenie „nawiedzenie” dotyczy przede wszystkim religijnego obszaru życia ${ }^{6}$. Osoba wierząca nawiedza kościół, by podejmować tam czynności religijne, modlić się, czyli wejść w relacje z Bogiem.

Nie zaprzeczając wartościom, jakie niesie za sobą zwiedzanie wybranego miejsca sakralnego, trzeba zarazem stwierdzić, że przede wszystkim ma się tam odbywać nawiedzanie. Wejście na teren sakralny jest nie tylko

${ }^{5}$ Przykładem może być muzeum kopalni soli w Bochni, gdzie pokazuje się pracujących górników, poruszające się postacie, przesuwające się wózki, a nawet symuluje się wybuchy gazów, które doprowadzają do tragedii.

${ }^{6}$ Stosowane jest także w tradycji tzw. nawiedzenia kościoła przez obraz świętego (Matki Bożej, patrona, relikwii). Jest to też akt natury religijnej, związany z bogatą obrzędowością. 
okazją do zapoznania się z wiarą chrześcijańską i jej zabytkami, ale jak podkreślono w dokumencie Stolicy Apostolskiej - „drogą przeżywania własnej wiary i świadczenia o niej" (Papieska Rada ds. Migracji i Podróżnych, 2001, nr 14). Jak już podkreślono, budowle sakralne są narzędziami służącymi do zapraszania do uczestnictwa w misterium, które się tam dokonuje. Stanowią zachętę do wejścia w relacje z Bogiem. Bez zrozumienia tej prawdy nie pojmiemy istotnego sensu ich egzystencji. Tu pojawia się pytanie autora, na które nie chce dać jednoznacznej odpowiedzi: czy turysta wchodzący do świątyni powinien być tylko niemym obserwatorem, czy też uczestnikiem dokonujących się tam wydarzeń, doświadczającym transcendencji? Odpowiedź twierdząca byłaby w mniemaniu autora zadowalająca, gdyż uważa on, że przewodnik chrześcijanin powinien pomóc turyście $\mathrm{w}$ takim pogłębionym przeżyciu obecności Boga wewnątrz obiektów sakralnych.

\section{6. „Neuroza turystyki”}

W kontekście niniejszego artykułu warto wspomnieć o zjawisku, które niekiedy nazywa się „neurozą wolnego czasu” (Ostrowski, 1996, s. 175, 250). Występuje ono w równym stopniu w świecie turystyki i może być nazwane „neurozą turystyki”. Zjawisko to polega na nieustannym pośpiechu i braku umiejętności zahamowania tempa życia, nawet w okresie poza pracą i codziennymi obowiązkami. W związku z tym człowiek chce w jak najkrótszym czasie zobaczyć jak najwięcej, a właściwie „zaliczyćc jak największą liczbę odwiedzonych miejsc, wyjechać jak najdalej. Wiąże się z tym chęć poszukiwania silnych wrażeń. Efektem takiego postępowania jest powierzchowność i płytkość odbioru. Człowiek potrzebuje czasu, by móc się skoncentrować oraz by przemyśleć i zinterioryzować poznawane wartości. Często okazuje się, że po zakończeniu podróży odbytej w pośpiechu w świadomości turysty pozostaje niewiele. Odnosi się to w szczególności do odwiedzania miejsc sakralnych. By odkryć pełnię ich wartości - bogatych i niełatwych w odbiorze - trzeba spokoju i czasu na zadumę. Przewodnik, który umiejętnie ogranicza tempo wędrówki i pozostawia chwile na osobistą refleksję, bynajmniej nie trwoni czasu turystów i nie zubaża programu wycieczki. Przeciwnie, w znacznym stopniu przyczynia się do wartościowszego jej przeżycia. Gdy weźmie się pod uwagę aktualne trendy, naturalnie nasuwa się pytanie, czy zrozumieją to wszyscy współcześni turyści. Sprawa wymaga wysiłków wychowawczych, a przecież należy się zgodzić, że przewodnik jest wychowawcą. 


\section{Równowaga między słowem a milczeniem}

Cechą przewodników, podobnie jak pedagogów, jest umiejętne operowanie słowem. Wiąże się to $\mathrm{z}$ ich zawodem. Turyści zatrudniają przewodników, nie tylko by prowadzili ich bezpiecznie po szlaku, ale także by przekazywali jak najwięcej informacji. Nie można się dziwić, że sami przewodnicy sądzą, iż skoro podjęli zobowiązanie i umówili się na konkretne wynagrodzenie, powinni przekazać turystom jak najwięcej wiadomości. Jednakże powstaje pytanie, czy obfitość słowa nie rodzi niekiedy przesytu. Sami odbiorcy mają ograniczoną recepcję treści i nie są w stanie przyswoić ich w nadmiarze. Może pojawić się wręcz zniechęcenie i znużenie. Wówczas zamiast przyjemności pozostają negatywne doznania. Człowiek (turysta) odbiera wartości nie tylko słuchem, ale też innymi zmysłami: wzrokiem (kształty, barwy), węchem (zapachy), dotykiem (bezpośredni kontakt z przedmiotem). W owej recepcji, jak już zresztą sygnalizowano, ważną rolę odgrywa cała gama uczuć, rozbudzonych np. poprzez atmosferę miejsca (gwar, cisza, gra świateł). Nie wszystko da się opowiedzieć. Trzeba zatem dać turyście czas na osobiste zatrzymanie się i przemyślenie tego, co odwiedza. Nie jest to bynajmniej stracony czas. Są to chwile dopełnienia w osobistej refleksji tego, co zostało przekazane przez słowa przewodnika. Teolog powie jeszcze dobitniej: najpierw sam człowiek spotyka się z sacrum, a przewodnik przez dobrze dobrane słowa wspomaga go, by to spotkanie nabierało głębi.

Ważną zdolnością przewodnika jest utrzymywanie równowagi między słowem a milczeniem. Powinien on bardziej inspirować turystów do osobistego namysłu i refleksji, które dokonują się właśnie w momencie indywidualnej zadumy. W świetle wcześniejszych akapitów niniejszego artykułu dotyczy to szczególnie miejsc sakralnych. Jak już bowiem zaznaczono, tego, co nadprzyrodzone, nie jesteśmy w stanie w pełni opisać ludzkimi słowami. Zawsze pozostaje to w jakimś stopniu otoczone tajemnica. Odkrycie jej wymaga zadumy i refleksji. Trzeba zatem dać turystom czas na osobiste przemyślenia, kontemplatywne pochylenie się nad oglądanymi obiektami. Należy także uwzględnić fakt, że w prowadzonej grupie są osoby wierzące i pragnące choćby przez moment zatrzymać się w sakralnym miejscu na modlitwę.

Naturalnie, zdarzają się grupy specjalistów bądź hobbystów, których interesuje zdobywanie jak największej ilości wiedzy. Wtedy jednak zmienia się typ wędrowania, nazywamy je wycieczką edukacyjną bądź szkoleniową. Wówczas wskazany jest szerszy wykład. Konkludując, teolog musi powiedzieć, że wejście w obręb sakralnych obiektów jest niezwykłą 
szansą prowadzenia człowieka ku religijnej wierze i jej rozwojowi. Tu rodzi się postulat pod adresem przewodników, którzy są wierzącymi chrześcijanami. Powinni zdawać sobie sprawę z tego, że - zgodnie z dokumentem przygotowanym w Stolicy Apostolskiej przez Papieską Radę ds. Migracji i Podróżnych (2001) - są nie tylko informatorami, ale poniekąd także katechetami i ewangelizatorami. Naturalnie są przewodnicy, którzy nie przyznają się do chrześcijańskiej wiary, ale oni również powinni zdać sobie sprawę z tego, że wprowadzając turystów do sakralnych obiektów, wchodzą w przestrzeń innego rodzaju. Zobowiązani są do przekazania odwiedzającym prawdy o właściwym sensie powstania i istnienia tych obiektów, a zarazem zachowania szacunku wobec przekonań ich twórców.

Autor artykułu świadomie nie omówił szerzej spraw dotyczących przewodnictwa w sakralnych obiektach, które wydają się oczywiste i nie ma potrzeby ich powtarzać. Przewodnik powinien dbać o to, by nie oprowadzać grupy podczas trwania nabożeństwa, dyskretnie zwracać uwagę turystów na kulturę zachowania, uszanowanie zwyczajów miejsca i godny ubiór. Wewnątrz obiektu powinien być oszczędny w słowach, a szczegółowe informacje przekazywać przed wejściem (por. Dziesięć przykazań..., 2018).

\section{Bibliografia}

Benedykt XVI (2011). Kontemplacja piękna dzieł sztuki droga do Boga, katecheza podczas audiencji w Castel Gandolfo 31.08.2011. Pobrane z: https://liturgia.wiara.pl/doc/934657. Kontemplacja-piekna-dziel-sztuki-droga-do-Boga (12.11.2018).

Dziesięć przykazań przewodnika po sakralnych obiektach (2018). Pobrane z: http://www.duszpasterstwo-pielgrzym.krakow.pl/index.php?show=rady1 (12.11.2018).

Grodź, S. (2002). Sacrum. W: M. Rusecki, K. Kaucha, I.S. Ledwoń, J. Mastej (red.), Leksykon teologii fundamentalnej (s. 1058-1059). Lublin-Kraków: Wydawnictwo M.

Hani, J. (1998). Symbolika światyni chrześcijańskiej. Kraków: Wydawnictwo Znak.

Jan Paweł II (1985). List do młodych całego świata, 31 marca 1985. Kraków: [b.w.].

Jan Paweł II (1997). Homilia w kościele Niepokalanego Serca Maryi, Zakopane - Krzeptówki, 7 czerwca 1997. W: Jan Pawet II w Polsce. Przemówienia i homilie, Polska, 2 VI 1979-10 VI 1979 (s. 141-147). Kraków: Społeczny Instytut Wydawniczy ZNAK.

Jan Paweł II (1999). List do artystów, 4 kwietnia 1999. Pobrane z: http://www.vatican.va/content/john-paul-ii/pl/letters/1999/documents/hf_jp-ii_let_23041999_artists.pdf (12.11.2018).

Katechizm Kościoła katolickiego (1994). Poznań: Pallottinum.

Kobielus, S. (2009). Mur. W: Encyklopedia katolicka. T. 13 (s. 505-506). Lublin: Towarzystwo Naukowe Katolickiego Uniwersytetu Lubelskiego Jana Pawła II.

Konieczny, M. (2012). Poświęcenie kościoła. W: Encyklopedia katolicka. T. 16 (s. 97). Lublin: Towarzystwo Naukowe Katolickiego Uniwersytetu Lubelskiego Jana Pawła II.

Nadolski, B. (2006). Leksykon liturgii. Poznań: Pallottinum,

Odwiedziny (2018). W: Słownik języka polskiego. Pobrane z: https://sjp.pwn.pl/slowniki/ odwiedziny.html (15.11.2018). 
Ostrowski, M. (1996). Duszpasterstwo wobec problemu wolnego czasu człowieka. Aspekt moralno-pastoralny ze szczególnym uwzględnieniem zagadnień turystyki. Kraków: Wydawnictwo Naukowe PAT.

Ostrowski, M. (2001). Ekologia w oczach turysty i pielgrzyma. W: A. Dyduch-Falniowska, M. Grzegorczyk, J. Perzanowska, Z. Kijas, Z. Mirek (red.), Mówić o przyrodzie. Zintegrowana wizja przyrody (s. 53-66). Kraków: Instytut Ochrony Przyrody PAN.

Pismo Święte Starego i Nowego Testamentu (2012). Poznań: Pallotinum.

Papieska Rada ds. Migracji i Podróżnych (2011). Wskazania dla duszpasterstwa turystycznego. Pobrane z: http://migracja.episkopat.pl/wp-content/uploads/2016/12/Wskazania-dla-duszp-turyst-PL.pdf (15.11.2018).

Paszkowska, T. (2002). Konsekracja. W: M. Chmielewski (red.), Leksykon duchowości katolickiej (s. 428). Lublin-Kraków: Wydawnictwo M.

Schlußerklärung (Dokument kończący IV Światowy Kongres Duszpasterstwa Turystycznego) (1991). W: Katholisches Auslandsseketariat, Pastoral Information. T. XXIV (s. 58). Bonn: [b.w.].

Seibert, J. (2007). Leksykon sztuki chrześcijańskiej. Tematy, postacie, symbole. Kielce: Wydawnictwo Jedność.

Żądło, A. (2012). Poświęcenie. W: Encyklopedia katolicka. T. 16 (s. 96). Lublin: Towarzystwo Naukowe Katolickiego Uniwersytetu Lubelskiego Jana Pawła II.

\title{
PRZEWODNICTWO W SAKRALNYCH OBIEKTACH
}

\begin{abstract}
Abstrakt: Autor przedstawia postulaty pod adresem przewodników oprowadzających turystów po obiektach sakralnych (sanktuariach, kościołach, klasztorach, ośrodkach pielgrzymkowych itp.). Wychodzi od teologicznego rozumienia sacrum i profanum oraz objaśnia cel tworzenia obiektów sakralnych. Powstają one, by zapewnić odpowiednie warunki do modlitwy i refleksji nad ostatecznym celem życia człowieka. Ich architektura, wystrój i atmosfera pomagają osobom wierzącym w poznaniu prawdy o Bogu i stanowią zachętę do wejścia z nim w osobiste relacje. Stanowią one dla odwiedzających $t z w$. Biblia pauperum. Ponadto poprzez rozwijający się w nich kult, sacrum rozlewa się na świat i ma go udoskonalać. Są one zatem swoistym narzędziem, łączącym sferę nadprzyrodzoną z tym, co ziemskie. Kościoły nie są martwymi muzeami, a obrzędy w nich odprawiane nie stanową "religijnego teatru”. Są to miejsca trwającego i rozwijającego się tu i teraz życia religijnego. Stąd odpowiednim słowem określającym znalezienie się w obrębie obiektu sakralnego jest zaczerpnięte z ewangelii „nawiedzanie”, czyli wejście w relacje, w opozycji do wyrazu „zwiedzanie”, oznaczającego jedynie zaspokajanie ciekawości. Zadaniem przewodników jest pomaganie turystom w odkrywaniu właściwego sensu istnienia obiektów sakralnych, poprzez odpowiednie objaśnienie znajdujących się w nich obrazów, symboli i sprawowanych tam obrzędów. Autor przestrzega przed zbyt pospiesznym odwiedzaniem sakralnych miejsc, ponieważ w ten sposób nie można dojrzeć ich głębi. Przewodnikom sugeruje oszczędność słów. Milcząca refleksja może dać więcej niż obfitość słów i nie jest dla turysty straconym czasem. W konkluzji autor stwierdza, że przewodnicy wierzący są dla turystów swoistymi ewangelizatorami i katechetami. Natomiast przewodnicy o innym światopoglądzie powinni przynajmniej przekazać prawdę i uszanować atmosferę sacrum.
\end{abstract}

Słowa kluczowe: obiekt sakralny, sacrum, profanum, przewodnik, postulaty pod adresem przewodników. 


\section{TOURIST GUIDES IN SACRED PLACES}

Abstract: The author presents the requirements for guides to show tourists around sacred buildings (sanctuaries, churches, monasteries, pilgrimage centers etc). He begins with a theological understanding of sacrum and profanum, and then explains the purpose of the sacred places which is to provide the proper conditions for prayer and reflection on the ultimate goal of human life. The architecture, decor and atmosphere help a believer become familiar with the truth about God and encourage him or her to enter into a personal relationship with him. Together they constitute a so-called "biblia pauperum" for visitors. On the other hand, through the cult which has developed there, the sacrum spreads out into the world with the intention of improving it. They are therefore a kind of tool connecting the supernatural realm with things seen as earthly. Churches are not dead museums, and the rites held in them do not constitute "religious theater". These are places of the here and now and exist to develop the religious life. Thus, the appropriate way of describing entrance to a sacred place should be one borrowed from the gospel - "visiting" - entering into a relation, as opposed to "sightseeing" which only refers to satisfying curiosity. A guide's task is to help tourists discover a proper sense of the existence of sacred places through an appropriate explanation of the images, symbols and rituals that are celebrated there. The author warns against visiting sacred places in a too hasty way which does not allow an appropriate insight into the "depth" of the place visited. Guides are recommended to be concise. Silent reflection gives more than any abundance of words and is not time lost for a tourist. In conclusion, the author states that believers working as guides can become evangelizers and catechists for tourists, however those with a different worldview should at least convey the truth and respect the atmosphere of the sacrum.

Keywords: sacral objects, sacrum, profanum, guide, requirements for guides. 